\title{
REAKSI PASAR MODAL INDONESIA TERHADAP PERISTIWA PERANG DAGANG AMERIKA SERIKAT DAN CHINA
}

\author{
Yani Rahmawati ${ }^{1)}$, Hendra Gunawan ${ }^{2)}$ \\ Program Studi Akuntansi Manajerial, Politeknik Negeri Batam \\ Jl. Ahmad Yani, Batam Center, Batam 29461, Indonesia \\ ${ }^{1}$ E-mail: yaniirahmaa@gmail.com \\ ${ }^{2}$ E-mail: hendra@polibatam.ac.id
}

\begin{abstract}
This research is an event study which aims to analyze the reaction of the Indonesian capital market, especially on LQ45 shares before and after political events that occur abroad. The event that became the object of observation was the trade war that occurred between the United States and China by using 12 events related to trade wars starting from 2014 to 2019, using the abnormal return indicator. The sample in this study are companies that are in the LQ45 stock index. The data used is secondary data in the form of the company's daily closing price and the Composite Stock Price Index (CSPI). The statistical test used to test the research hypothesis is the paired t-test which was tested on 11 events, and there was 1 event using the Wilcoxon test. The results showed that the trade war between the United States and China did not result in a significant difference in abnormal returns on LQ45 stocks with the observed period. So it can be said that the Indonesian capital market did not react to the 12 events of the trade war between the United States and China.
\end{abstract}

Keywords: Abnormal Return, LQ45 Stock, Event Study, Capital Market

\begin{abstract}
ABSTRAK
Penelitian ini merupakan event study yang bertujuan untuk menganalisis reaksi pasar modal Indonesia khususnya pada saham LQ45 sebelum dan setelah peristiwa politik yang terjadi di luar negeri. Peristiwa yang menjadi objek pengamatan adalah perang dagang yang terjadi antara negara Amerika Serikat dan China dengan menggunakan 12 peristiwa terkait perang dagang yang dimulai dari tahun 2014 hingga 2019, dengan menggunakan indikator abnormal return. Sampel dalam penelitian ini adalah perusahaan yang berada dalam indeks saham LQ45. Data yang digunakan merupakan data sekunder berupa harga penutupan saham harian perusahaan, dan Indeks Harga Saham Gabungan (IHSG). Uji statistik yang digunakan untuk menguji hipotesis penelitian adalah uji paired t-test yang diujikan pada 11 peristiwa, dan terdapat 1 peristiwa menggunakan uji wilcoxon. Hasil penelitian menunjukkan bahwa peristiwa perang dagang Amerika Serikat dan China tidak mengakibatkan perbedaan abnormal return yang signifikan pada saham LQ45 dengan periode pengamatan. Sehingga dapat dikatakan pasar modal Indonesia tidak bereaksi terhadap 12 peristiwa perang dagang Amerika Serikat dan China.
\end{abstract}

Kata Kunci: Abnormal Return, Saham LQ45, Studi Peristiwa, Pasar Modal 


\section{PENDAHULAN}

Pasar modal merupakan sarana pendanaan bagi perusahaan maupun institusi. Pasar modal adalah pasar di mana berbagai instrumen keuangan jangka panjang dapat diperjualbelikan, baik dalam bentuk surat utang (obligasi), reksa dana, saham, instrumen derivatif maupun instrumen lainnya. Pasar modal merupakan sarana untuk kegiatan investasi. Instrumen jangka panjang yang diperjualbelikan seperti saham, reksa dana, obligasi, right, waran, dan instrumen derivatif seperti futures, option dan lain-lain (www.idx.co.id) ${ }^{1}$.

Menurut Undang-Undang No. 8 Tahun 1995 tentang Pasar Modal disebutkan bahwa pasar modal merupakan kegiatan yang bersangkutan dengan penawaran umum dan perdagangan efek. Penawaran umum merupakan kegiatan penawaran efek yang dilakukan oleh emiten untuk menjual efek kepada masyarakat. Efek merupakan surat berharga, seperti surat pengakuan utang, surat berharga komersial, saham, obligasi, kontrak berjangka dan setiap derivatif dari efek. Pasar modal memiliki peran strategis dalam pembangunan nasional sebagai salah satu sumber pembiayaan bagi dunia usaha dan wahana investasi bagi masyarakat.

Salah satu yang diperjualbelikan dalam pasar modal ialah saham. Saham merupakan salah satu pilihan untuk kegiatan pendanaan perusahaan. Salah satu faktor yang dapat mempengaruhi pasar saham ialah faktor non ekonomi yaitu peristiwa politik. Salah satu peristiwa politik yang dapat mempengaruhi pasar saham adalah pergantian pemimpin dan pemerintahan.

Kebijakan yang dibuat pemimpin baru dapat mempengaruhi kondisi ekonomi di masa datang (Hung, 2013). Situasi politik dapat mempengaruhi pengembalian saham, begitu pula dengan kebijakan ekonomi yang dapat mempengaruhi pergerakan harga saham (Li \& Peng, 2017; Gutierrez \& Vianna, 2018).
Pemilihan presiden Amerika Serikat tahun 2016 merupakan salah satu peristiwa politik global yang paling berefek pada pasar keuangan global (Shaikh, 2017). Pasar saham Amerika Serikat sangat responsif ketika Trump menjadi calon dari partai Republik (Pham, Ramiah, Moosa, Huynh, \& Pham, 2018). Terpilihnya Donald Trump sebagai presiden Amerika Serikat mengejutkan sebagian besar pengamat pasar dengan membawa kebijakan yang dinilai bersifat menyebabkan reaksi di pasar keuangan (Shaikh, 2017). Ketidakpastian politik yang bersumber dari pemilihan presiden Amerika Serikat cenderung membuat pasar keuangan sangat fluktuatif (Pham, Ramiah, Moosa, Huynh, \& Pham, 2018). Donald Trump membuat kebijakan perdagangan menuju lebih proteksionisme dan bersikap musuh terhadap perdagangan bebas global, serta kenaikan tarif impor (Cheong \& Tongzon, 2018).

Beberapa kebijakan ekonomi Trump diperkirakan mempengaruhi semua sektor ekonomi (Pham, Ramiah, Moosa, Huynh, \& Pham, 2018). Mengutip dari kompas.com (19 Juli 2018), kebijakan Donald Trump yang mengguncang ekonomi global diantaranya kebijakan penurunan tingkat pajak, pembatasan ekspor teknologi canggih serta kebijakan tarif. Salah satu kebijakan yang dianggap kontroversial adalah pemberlakuan tarif dagang, salah satu negara yang sudah menjadi target kebijakan tarif Amerika Serikat adalah China. China menjadi target utama Amerika Serikat yang merupakan upaya Amerika Serikat dalam melaksanakan perang dagang. Penetapan tarif oleh Amerika Serikat terhadap barang-barang China serta balasan penetapan tarif terhadap barang impor dari Amerika Serikat mengawali perang dagang antar kedua negara (Steinbock, 2018).

Penelitian ini merupakan pengembangan event study dari penelitian Pham, Ramiah, Moosa, Huynh, \& Pham (2018) serta penelitian Wagner, Zechauser, \& Ziegler (2017). Penelitian Pham, Ramiah, Moosa, Huynh, \& Pham (2018) menggunakan metode event study dengan menganalisis 47 
peristiwa dimulai dengan Trump mengumumkan ia akan bergabung dalam pemilihan presiden hingga pemilihan presiden Amerika Serikat. Hasil penelitian Pham, Ramiah, Moosa, Huynh, \& Pham (2018) menunjukkan bahwa pasar saham bereaksi terhadap beberapa peristiwa. Ketidakpastian sebelum pemilihan menghasilkan dampak buruk bagi pasar yang cenderung bereaksi turun hampir di semua sektor.

Penelitian Wagner, Zechauser \& Ziegler (2017) menganalisis respon harga saham terhadap kebijakan kandidat pemenang presiden. Kebijakan yang dipilih terkait kebijakan perdagangan dan kebijakan pajak oleh Trump. Hasil penelitian tersebut menunjukkan bahwa ekspektasi terhadap kebijakan pemotongan pajak perusahaan besar serta kebijakan tarif secara substansial berdampak pada pengembalian saham.

Perbedaan penelitian ini dengan penelitian sebelumnya ialah, pada penelitian ini peneliti menggunakan event study yaitu peristiwa perang dagang Amerika Serikat dan China. Penelitian ini menguji 12 peristiwa yang terjadi selama perang dagang Amerika Serikat dan China terjadi. Penelitian ini menggunakan data penutupan harga saham harian perusahaan yang termasuk dalam indeks LQ45 pada periode peristiwa. Tujuan penelitian ini ialah untuk menganalisis perbedaan abnormal return pada saham LQ45 pada 12 peristiwa yang terjadi selama perang dagang Amerika Serikat dan China.

\section{KAJIAN LITERATUR}

\section{Event Study}

Event study atau studi peristiwa adalah studi yang mempelajari tentang reaksi pasar terhadap suatu peristiwa (event) yang informasinya dipublikasikan sebagai suatu pengumuman. Event study dapat digunakan untuk menguji informasi dalam suatu pengumuman, selain itu event study juga dapat digunakan untuk menguji efisiensi pasar bentuk setengah kuat (semi strong form). Pengujian kandungan informasi yang dimaksudkan ialah untuk melihat reaksi dari suatu pengumuman. Reaksi pasar dapat diukur dengan menggunakan return sebagai nilai perubahan atau menggunakan abnormal return. Pengumuman dikatakan memiliki kandungan informasi apabila memberikan abnormal return kepada pasar begitu pula sebaliknya jika tidak memberikan abnormal return pasar maka pengumuman tidak mengandung informasi (Hartono, 2015). Event study merupakan metode alternatif yang digunakan untuk memeriksa kinerja abnormal return dengan informasi dari suatu peristiwa yang diindentifikasi (Dyckman, Philbrick \& Stephan, 1984).

\section{Pasar Modal}

Pasar modal merupakan sarana atau tempat bertemunya antara pemintaan dan penawaran atas instrumen keuangan jangka panjang (Sutedi, 2013). Bentuk instrumen pada pasar modal disebut efek. Instrumen yang dimaksud adalah instrumen derivatif maupun instrumen lainnya. Adapun Instrumen pasar modal yaitu derivatif, saham, obigasi dan reksa dana.

Derivatif merupakan produk turunan dari pasar modal. Contoh produk derivatif di pasar modal berupa indeks harga saham dan indeks kurs obligasi (Samsul, 2006). Saham (stock) adalah salah satu instrumen yang diperjualbelikan dalam pasar modal. Saham merupakan instrumen yang banyak dipilih pasar investor ketika berinvestasi. Suatu perusahaan dapat menjual hak kepemilikan dalam bentuk saham (Hartono, 2015).

Obligasi merupakan salah satu instrumen yang diperjualbelikan di pasar modal. Obligasi ialah suatu utang atau kewajiban jangka panjang yang akan dibayar kembali pada saat jatuh tempo. Nilai utang dari obligasi tersebut dinyatakan di dalam surat utang. Berdasarkan Undang-Undang No.8 Tahun 1995 tentang Pasar Modal, reksa dana merupakan tempat yang digunakan untuk menghimpun dana dari masyarakat pemodal yang selanjutnya diinvestasikan dalam portofolio efek. 


\section{Perdagangan}

Menurut Undang-Undang No. 7 Tahun 2014 tentang Perdagangan menerangkan perdagangan disebutkan susunan kegiatan yang berkaitan dengan transaksi barang dan/atau jasa di dalam negeri dan melampaui batas wilayah negara dengan tujuan pengalihan hak atas barang dan/atau jasa untuk memperoleh imbalan atau kompensasi. Perdagangan dibagi menjadi perdagangan dalam negeri dan perdagangan luar negeri. Salah satu ruang lingkup perdagangan merupakan perdagang internasional, dalam hal ini dikaitkan dengan kegiatan ekspor dan impor (Anindita \& Reed, 2008).

Perdagangan dalam negeri merupakan perdagangan barang maupun jasa dalam wilayah Negara Kesatuan Republik Indonesia yang isinya tidak termasuk perdagangan luar negeri. Sedangkan perdagangan luar negeri merupakan perdagangan yang di dalamnya mencakup kegiatan ekspor dan/atau impor atas barang dan/atau jasa yang melewati batas suatu wilayah negara.

Perdagangan internasional merupakan bagian dari perdagangan luar negeri yang didalamnya mencakup kegiatan ekspor dan impor. Perdagangan Internasional merupakan kegiatan yang dilakukan yang diawali dengan sebuah kesepakatan kerjasama antar negara atau pemerintahan. Salah satu jenis kegiatan dalam perdagangan internasional merupakan kegiatan ekspor dan impor (Anindita \& Reed, 2008).

\section{Literatur}

Penelitian oleh Pham, Ramiah, Moosa, Huynh, \& Pham (2018) menguji 47 peristiwa terkait dengan pencalonan Trump sebagai calon presiden Amerika Serikat pada tahun 2016. Pengujian tersebut menguji bagaimana pengembalian di pasar saham Amerika Serikat sebagai reaksi terhadap peristiwa yang berkaitan dengan pencalonan Trump sebagai presiden. Hasil penelitian tersebut menunjukkan adanya reaksi pasar terhadap beberapa peristiwa menjelang pemilihan presiden dan reaksi terbesar ditunjukkan pada saat Donald Trump dipastikan menjadi nominasi dari partai Republik.

Penelitian Wagner, Zechauser \& Ziegler (2017) berfokus pada prediksi respon saham terhadap pemilihan umum dalam jangka pendek dan jangka panjang. Penelitian tersebut menelusuri reaksi pasar saham Amerika dari hari sebelum pemilihan presiden Trump hingga seratus hari pertama Trump menjabat. Hasil menunjukkan bahwa harga saham relatif merespon. Hasil penelitian tersebut juga menunjukkan bahwa kebijakan terkait pemotongan pajak perusahaan besar oleh Trump secara substansial berdampak pada pengembalian harga saham, khususnya perusahaan yang membayar pajak tinggi.

Penelitian Gutierrez \& Vianna (2018) menganalisis efek dari komoditas baja terhadap pengembalian pasar saham di negara berkembang dan ekonomi maju terkait dengan kebijakan Amerika Serikat. Hasil penelitian tersebut menunjukkan adanya respon positif yang signifikan dari negara maju seperti Australia, Jepang dan Korea Selatan. Berbanding terbalik dengan pasar komoditas baja yang menunjukkan kerugian yang lebih besar akibat kenaikan tarif impor baja.

Reaksi pasar modal juga ditunjukan pada penelitian Ridwan (2018) yang menganalisis respon dari investor saham terhadap pergantian Menteri Keuangan Republik Indonesia pada tanggal 20 Mei 2013. Hasil penelitian tersebut menunjukkan bahwa pergantian Menteri Keuangan pada tanggal 20 Mei 2013 tidak memiliki dampak yang signifikan pada return dan abnormal return yang akan diperoleh investor sebelum, saat dan setelah pergantian Menteri Keuangan Indonesia.

Event study juga dilakukan pada penelitian Nazir, Younus, Kaleem \& Anwar (2014) yang meneliti hubungan antara peristiwa politik yang tidak pasti dan pasar saham Pakistan dari Mei 1999 hingga Desember 2011. Menggunakan model pengembalian rata-rata yang disesuaikan dan event study methodology dengan membandingkan efisiensi pasar antara dua 
gaya pemerintahan yaitu otokratis dan demokratis. Hasil penelitian tersebut menunjukkan bahwa peristiwa politik berdampak pada pengembalian pada bursa saham Karachi.

Hasil penelitian tersebut menunjukkan bahwa pasar saham Pakistan tidak efisien untuk waktu yang singkat. Hanya tujuh dari 20 peristiwa yang menunjukkan perbedaan signifikan dalam abnormal return selama dua hari sebelum dan sesudah peristiwa. Indeks KSE 100 tidak merespon secara signifikan terhadap semua peristiwa politik.

Penelitian Nugraha \& Suroto (2019) yang meneliti reaksi investor pasar modal Indonesia terhadap peristiwa pemilihan presiden tahun 2019. Sampel yang digunakan pada penelitian tersebut adalah perusahaan yang termasuk dalam indeks LQ45 selama penelitian tersebut dilakukan dengan indeks komposit harian tiga hari sebelum dan tiga hari setelah acara. Uji yang dilakukan dengan menggunakan uji-t satu sampel dan uji-t berpasangan. Hasil penelitian tersebut menunjukkan bahwa terdapat abnormal return yang positif serta signifikan pada harihari sekitar acara terutama pada hari ketiga $(\mathrm{t}+3)$ setelah acara. Selain itu terdapat perbedaan yang tidak signifikan dalam ratarata trading volume, namun berbeda dengan abnormal return yang menunjukkan tidak ada perbedaan pada hari sebelum dan sesudah event.

Penelitian Elad (2016) menguji pengaruh berita akuisisi terhadap return saham perusahaan. Data yang digunakan untuk dianalisis dari bulan Juli 2012 hingga Mei 2013. Penelitian tersebut mengamati 51 perusahaan yang mengakuisisi dengan saham yang diperdagangkan secara terbuka di London Stock Exchange (LSE). Periode estimasi berlangsung dari hari -100 hingga 10 hari sementara untuk periode pengujian dari -5 hingga +5 dengan menggunakan capital market untuk memprediksi saham di masa depan dan regresi sederhana untuk mendapatkan parameter dari persamaan regresi. Hasil statistik yang diperoleh ratarata secara signifikan positif. Dapat dikatakan bahwa peristiwa akuisisi terkait secara signifikan dengan abnormal return.

Penelitian Saraswati \& Mustanda (2018) menguji reaksi dari pasar modal Indonesia terhadap peristiwa pengumuman hasil perhitungan suara pemilihan umum serta pelantikan Presiden Amerika Serikat. Penelitian tersebut menggunakan data perusahaan yang terdaftar dalam Indeks LQ45 periode Agustus 2016. Penelitian tersebut menunjukkan bahwa terdapat perbedaan abnormal return sebelum dan setelah pada peristiwa pengumuman hasil perhitungan suara pemilihan umum presiden Amerika Serikat.

Peristiwa pelantikan presiden Amerika Serikat menunjukkan adanya perbedaan abnormal return sebelum dan sesudah peristiwa terjadi antara tahun 1963 dan 2012 (Hobbs, Schaupp, \& Gingrich, 2016). Penelitian ini berfokus pada 28 acara yang memiliki profile tinggi selama 50 tahun terkahir. Hasil penelitian menunjukkan bahwa abnormal return secara signifikan lebih rendah untuk industri yang memang diprediksi paling dirugikan daripada industri lain.

Kebijakan Trump terkait perdagangan global memberikan dampak pada pasar dunia. Ketua Umum Asosiasi Perusahaan Efek Indonesia (APEI), Budiyanto (2019) menilai bahwa perang dagang Amerika Serikat dan China memberikan dampak yang membahayakan bagi perekonomian global. Bagi pasar saham dalam negeri perang dagang akan berdampak dalam jangka pendek karena terimbas koreksinya bursa saham global ${ }^{2}$.

Penelitian ini menggunakan peristiwa perang dagang Amerika Serikat dan China untuk melihat reaksi pasar dalam negeri dengan menggunakan 12 event yang terjadi pada perang dagang Amerika Serikat dan China. Sehingga peneliti berasumsi bahwa

\footnotetext{
${ }^{2}$ Dapat di akses di https://www.cnbcindonesia.com/market/201905141 00429-17-72272/perang-dagang-dimulai-ini-dampakke-bursa-saham-perbankan
} 
perang dagang Amerika Serikat dan China memberikan pengaruh terhadap reaksi pasar saham di Indonesia. Reaksi pasar diproksikan dengan abnormal return. Berdasarkan penjelasan di atas hipotesis alternatif pada penelitian ini adalah:

H1 : Terdapat perbedaan abnormal return sebelum dan setelah peristiwa terkait perang dagang Amerika Serikat dan China pada saham LQ45.

Hipotesis pada penelitian ini diujikan pada 12 event tekait peristiwa perang dagang Amerika Serikat dan China dari tahun 2014 hingga 2019, 12 event yang digunakan pada penelitian ini dapat dilihat pada Tabel 1.

Tabel 1

12 event pada peristiwa perang dagang Amerika Serikat dan China

\begin{tabular}{|c|c|c|c|}
\hline \multicolumn{4}{|c|}{ China } \\
\hline No & Day & Event & Sumber \\
\hline 1 & $\begin{array}{l}19 \\
\text { Mei } \\
2014\end{array}$ & $\begin{array}{l}\text { Trump membuat } \text { tweet pada Mei } \\
\text { 2014, yang menyerukan } \\
\text { perlawanan terhadap praktik } \\
\text { perdagangan China ("Ingat, China } \\
\text { bukan teman Amerika Serikat!") }\end{array}$ & $\begin{array}{l}\text { https://www.cnbcin } \\
\text { donesia.com/20190 } \\
\text { 630102650-4- } \\
81640 /\end{array}$ \\
\hline 2 & $\begin{array}{l}1 \mathrm{Mei} \\
2016\end{array}$ & $\begin{array}{l}\text { Penekanan kampanye Trump atas } \\
\text { dugaan pelanggaran perdagangan } \\
\text { China. Yang disampaikan pada } \\
\text { rapat umum di Indiana Mei } 2016 .\end{array}$ & $\frac{\underline{\text { https://www.bbc.co }}}{\underline{\text { m/indonesia/dunia/ }}}$ \\
\hline 3 & $\begin{array}{l}\text { 22 Jan } \\
2018\end{array}$ & $\begin{array}{l}\text { Amerika Serikat kenakan Bea } \\
\text { Masuk 30\% untuk Sel Surya dan } \\
\text { Mesin Cuci }\end{array}$ & $\begin{array}{l}\frac{\text { https://www.cnbcin }}{\text { donesia.com/ }} \\
\frac{\text { news/20180123163 }}{157-4-2304 /}\end{array}$ \\
\hline 4 & $\begin{array}{l}08 \\
\text { Mar } \\
2018\end{array}$ & $\begin{array}{l}\text { Trump mengesahkan tarif masing- } \\
\text { masing sebesar } 25 \% \text { dan } 10 \% \\
\text { untuk impor baja dan aluminium. }\end{array}$ & $\frac{\underline{\text { https://economy.oke }}}{\underline{\text { zone.com/read2018/ }}}$ \\
\hline 5 & $\begin{array}{l}04 \\
\text { April } \\
2018\end{array}$ & $\begin{array}{l}\text { Tindakan Balasan oleh pemerintah } \\
\text { AS dengan mengenakan bea masuk } \\
\text { sebesar } 25 \% \text { terhadap } 1.300 \text { produk } \\
\text { impor Cina. }\end{array}$ & $\begin{array}{l}\text { https://www.bbc.co } \\
\text { m/indonesia/dunia- } \\
43637257\end{array}$ \\
\hline 6 & $\begin{array}{l}17 \\
\text { Sept } \\
2018\end{array}$ & $\begin{array}{l}\text { Trump mengancam memberikan } \\
\text { tarif tambahan pada produk China } \\
\text { dari } 10 \% \text { menjadi } 25 \% \text { apabila } \\
\text { Beijing membalas. }\end{array}$ & $\begin{array}{l}\frac{\text { https://www.cnbcin }}{\text { donesia.com/ }} \\
\text { 20190630102650- } \\
\text { 4-81640/ }\end{array}$ \\
\hline 7 & $\begin{array}{l}18 \\
\text { Sept } \\
2018\end{array}$ & $\begin{array}{l}\text { China merencanakan akan } \\
\text { menambah tarif US } \$ 60 \text { miliar } \\
\text { pada produk AS sebagai tanggapan } \\
\text { atas bea masuk AS terbaru }\end{array}$ & $\begin{array}{l}\frac{\text { https://www.cnbcin }}{\text { donesia.com/ }} \\
\underline{20190630102650-} \\
\underline{4-81640 /}\end{array}$ \\
\hline 8 & $\begin{array}{l}\text { 01 Des } \\
2018\end{array}$ & $\begin{array}{l}\text { AS setuju untuk menunda rencana } \\
\text { kenaikan tarif sebesar US } \$ 200 \\
\text { miliar pada barang-barang China } \\
\text { menjadi } 25 \% \text { dari } 10 \% \text {. (Berharap } \\
\text { kesepakatan negosiasi) }\end{array}$ & $\frac{\frac{\text { https://www.cnbcin }}{\text { donesia.com/ }}}{\text { 20190630102650- }}$ \\
\hline 9 & $\begin{array}{l}05 \\
\text { Mei } \\
2019\end{array}$ & $\begin{array}{l}\text { Peringatan kembali Trump akan } \\
\text { meningkatkan tarif pada barang- } \\
\text { barang China. }\end{array}$ & $\begin{array}{l}\frac{\text { https://www.cnbcin }}{\text { donesia.com/ }} \\
\frac{20190630102650-}{4-81640 / .}\end{array}$ \\
\hline
\end{tabular}

\begin{tabular}{|c|c|c|c|}
\hline 10 & $\begin{array}{l}10 \\
\text { Mei } \\
2019\end{array}$ & $\begin{array}{l}\text { Tarif pada barang-barang China } \\
\text { sebesar US \$ } 200 \text { miliar meningkat } \\
\text { menjadi } 25 \% \text { dari } 10 \% \text {. }\end{array}$ & $\begin{array}{l}\frac{\text { https://www.cnbcin }}{\text { donesia.com/ }} \\
\frac{20190630102650-}{4-81640 / .}\end{array}$ \\
\hline 11 & $\begin{array}{l}29 \\
\text { Juni } \\
2019\end{array}$ & $\begin{array}{l}\text { Presiden Trump dan Presiden Xi } \\
\text { setuju untuk melanjutkan negosiasi } \\
\text { perdagangan selama pertemuan } \\
\text { yang sangat dinanti di sela-sela } \\
\text { KTT G-20 di Jepang. }\end{array}$ & $\begin{array}{l}\frac{\text { https://www.cnbcin }}{\text { donesia.com/20190 }} \\
\underline{\text { 630102650-4- }} \\
\underline{81640 /}\end{array}$ \\
\hline 12 & $\begin{array}{l}1 \\
\text { Agus } \\
2019\end{array}$ & $\begin{array}{l}\text { Pengumuman penetapan } 10 \% \\
\text { pajak tambahan atas barang impor } \\
\text { China senilai USS } 300 \text { milliar oleh } \\
\text { Trump. }\end{array}$ & $\begin{array}{l}\frac{\text { https://economy.oke }}{\text { zone.com/read/2019 }} \\
\text { I08/02/320/2086814 } \\
\end{array}$ \\
\hline
\end{tabular}

\section{METODE PENELITIAN}

Penelitian ini menggunakan pendekatan kuantitatif dengan bentuk data berupa harga saham harian indeks saham LQ45 selama periode penelitian. Data penelitian diperoleh dari Bursa Efek Indonesia yang dapat diakses di www.idx.co.id dan finance.yahoo.com. Metode penelitian yang digunakan pada penelitian ini merupakan metode event study. Metode event study digunakan untuk mengetahui adanya pengaruh terhadap suatu peristiwa (event). Event study atau studi kasus pada penelitian ini adalah peristiwa perang dagang Amerika Serikat dan China.

Populasi pada penelitian ini ialah perusahaan yang terdaftar dalam indeks LQ45 selama peristiwa Perang Dagang Amerika Serikat dan China berlangsung. Indeks saham LQ45 digunakan pada penelitian ini karena perusahaan yang dipilih berdasarkan likuiditas perdagangan saham dan disesuaikan setiap enam bulan (Hartono, 2015). Data yang digunakan berupa harga penutupan saham harian dari perusahaan LQ45 selama peristiwa perang dagang Amerika Serikat dan China berlangsung.

Variabel independen penelitian ini yaitu peristiwa perang dagang Amerika Serikat dan China. Variabel dependen pada penelitian ini adalah pergerakan saham yang dalam penelitian ini diwakili dengan abnormal return saham perusahaan. Proksi yang digunakan untuk mengukur reaksi pasar akibat terjadinya perang dagang Amerika Serikat dan China adalah abnormal return. Abnormal return merupakan selisih antara return sebenarnya dengan return ekspektasi. Return sebenarnya merupakan return yang 
terjadi pada waktu ke-t yang merupakan selisih harga sekarang dengan harga sebelumnya. Return estimasi merupakan return yang harus diestimasi.

Model estimasi yang dapat digunakan untuk mengestimasi return ekspektasi yaitu mean-adjusted model, market model dan market-adjusted model (Brown \& Warner, 1985). Penelitian ini menggunakan metode market-adjusted model. Adapun rumus menghitung return saham dengan mengabaikan deviden dapat dituliskan sebagai berikut:

$$
\text { RT Ni.t }=\frac{\left(P_{t}-P_{t-1}\right)}{P_{t-1}}
$$

di mana:

RT Ni.t : Return saham

$P t \quad$ : Harga saham period ke-t

Pt-1 : Harga periode sebelumnya (t-1)

Sedangkan untuk penghitungan return pasar rumus dapat dituliskan sebagai berikut:

$$
R m t=\frac{\left(I H S G_{t}-I H S G_{t-1}\right)}{I H S G_{t-1}}
$$

di mana:

Rmt : Return pasar (market return) waktu ke t

$I H S G t$ : Nilai IHSG pada saat $\mathrm{t}$

IHSGt-1 : Nilai IHSG pada saat t-1

Penelitian ini menggunakan market adjusted model sehingga return sekuritas yang diestimasi ialah sama dengan return indeks pasar.

ARit $=$ Rit - Rmt

di mana:

ARit : Abnormal return saham i pada hari ke-t

Rit : Actual return saham i pada hari ke-t

Rmt : Return pasar (menggunakan IHSG)

Data yang digunakan dalam penelitian ini merupakan data sekunder berupa harga penutupan saham perusahaan untuk mengetahui return saham selama periode peristiwa dan Indek Harga Saham Gabungan (IHSG) untuk mengetahui return pasar selama periode peristiwa. Data penelitian diperoleh dari Bursa Efek Indonesia yang dapat diakses di www.idx.co.id dan finance.yahoo.com. Data lain baik dalam bentuk definisi, teori atau informasi terkait penelitian didapatkan dari jurnal, buku-buku, dokumen, media cetak dan sebagianya. Penelitian ini menggunakan seluruh populasi yang ada di indeks saham LQ45. Saham LQ45 dijadikan sebagai populasi pada penelitian ini karena didasari oleh bahwa saham yang terdapat pada indeks LQ45 merupakan saham-saham yang paling aktif diperdagangkan (Hartono, 2015). Teknik pengumpulan data pada penelitian ini menggunakan arsip data dan teknik pengolahan data menggunakan tubulasi data.

Penelitian ini menggunakan market adjusted model atau model disesuaikan pasar. Market adjusted model digunakan untuk menghitung return ekspektasi yang artinya bahwa untuk mengestimasi return suatu sekuritas adalah menggunakan return pasar saat tersebut. Sehingga tidak perlu menggunakan periode estimasi untuk membentuk model estimasi karena return yang diestimasi sama dengan return pasar. Return pasar yang digunakan pada penelitian ini ialah Indeks Harga Saham Gabungan (IHSG). Teknik analisis data yang digunakan pada penelitian ini yaitu menggunakan uji t sampel berpasangan atau uji paired samples $t$ test serta menggunakan uji Wilcoxon untuk data yang tidak berdistribusi normal.

\section{HASIL DAN PEMBAHASAN}

Karakteristik responden dari penelitian ini meliputi saham yang berada pada indeks saham LQ45 serta sampel yang digunakan sebanyak 45 perusahaan saham LQ45. Data yang diunduh merupakan data penutupan saham untuk mengetahui return saham (Rit) dan return pasar mengacu pada Indeks Harga Saham Gabungan (IHSG) yang digunakan untuk mencari abnormal return (Arit) dengan waktu pengamatan -5 dan +5 pada setiap event. Penelitian ini menggunakan 
analisis event study yang digambarkan dengan 12 peristiwa terkait perang dagang Amerika Serikat dan China dimulai pada tahun 2014, 2016, 2018 dan 2019. Berikut merupakan jumlah sampel yang digunakan pada setiap event.

Tabel 2

Jumlah Sample setiap Event

\begin{tabular}{clc}
\multicolumn{3}{c}{ Jumlah Sample setiap Event } \\
\hline \multirow{2}{*}{ No. } & \multicolumn{1}{|}{ Keterangan Peristiwa } & Jumlah Sample \\
& & $(\mathrm{N})$ \\
\hline 1 & Event 1 (19 Mei 2014) & 44 \\
2 & Event 2 (1 Mei 2016) & 45 \\
3 & Event 3 (22 Januari 2018) & 45 \\
4 & Event 4 (08 Maret 2018) & 45 \\
5 & Event 5 (04 April 2018) & 39 \\
6 & Event 6 (17 September 2018) & 45 \\
7 & Event 7 (18 September 2018) & 41 \\
8 & Event 8 (01 Desember 2018) & 37 \\
9 & Event 9 (05 Mei 2019) & 43 \\
10 & Event 10 (10 Mei 2019) & 44 \\
11 & Event 11 (29 Juni 2019) & 41 \\
12 & Event 12 (1 Agustus 2019) & 45 \\
\hline
\end{tabular}

Data statistik deskriptif abnormal return di 12 peristiwa terkait perang dagang Amerika dan China dengan event window adalah $\mathrm{t}-5$ sebelum peristiwa dan $\mathrm{t}+5$ setelah peristiwa dapat dilihat pada Tabel 3. Data diolah untuk melihat nilai minimum, maksimum dan nilai rata-rata serta standar deviasi.

Tabel 3

Ringkasan Uji Statistik Deskripti Abnormal Return Saham LQ45

\begin{tabular}{clccccc}
\hline Event & Keterangan & $\mathrm{N}$ & Minimum & Maximum & Mean & $\begin{array}{c}\text { Std. } \\
\text { Deviation }\end{array}$ \\
\hline Event 1 & $A R$ Sebelum & 44 & $-0,025407$ & 0,026616 & 0,001203 & 0,009753 \\
& $A R$ Setelah & & $-0,013897$ & 0,012790 & 0,000416 & 0,005678 \\
\hline Event 2 & $A R$ Sebelum & 45 & $-0,018019$ & 0,017197 & $-0,000133$ & 0,008795 \\
& $A R$ Setelah & & $-0,027620$ & 0,013713 & $-0,003300$ & 0,010401 \\
\hline Event 3 & $A R$ Sebelum & 45 & $-0,010910$ & 0,031524 & 0,001430 & 0,008091 \\
& $A R$ Setelah & & $-0,016369$ & 0,027001 & 0,004004 & 0,010694 \\
\hline Event 4 & $A R$ Sebelum & 45 & $-0,020505$ & 0,011395 & $-0,002917$ & 0,006564 \\
& $A R$ Setelah & & $-0,020265$ & 0,022681 & $-0,000588$ & 0,008220 \\
\hline Event 5 & $A R$ Sebelum & \multirow{2}{*}{9} & $-0,013858$ & 0,011437 & $-0,000089$ & 0,005976 \\
& $A R$ Setelah & & $-0,009560$ & 0,016926 & 0,001554 & 0,006671 \\
\hline Event 6 & $A R$ Sebelum & 45 & $-0,014567$ & 0,019897 & $-0,000325$ & 0,008322 \\
& $A R$ Setelah & & $-0,017580$ & 0,018556 & 0,000808 & 0,006589 \\
\hline Event 7 & $A R$ Sebelum & 41 & $-0,017593$ & 0,017151 & $-0,001409$ & 0,007091 \\
& $A R$ Setelah & & $-0,013859$ & 0,015352 & 0,000725 & 0,005049 \\
\cline { 2 - 7 } Event 8 Sebelum & \multirow{2}{*}{37} & $-0,017967$ & 0,024341 & 0,002567 & 0,009860 \\
& $A R$ Setelah & & $-0,006472$ & 0,010128 & 0,000998 & 0,003659 \\
\hline Event 9 & $A R$ Sebelum & \multirow{2}{*}{43} & $-0,018859$ & 0,019300 & $-0,002495$ & 0,008492 \\
& $A R$ Setelah & & $-0,029083$ & 0,018728 & $-0,003500$ & 0,008779 \\
\hline Event 10 & $A R$ Sebelum & \multirow{2}{*}{44} & $-0,040013$ & 0,018367 & $-0,006051$ & 0,011309 \\
& $A R$ Setelah & & $-0,025466$ & 0,021219 & $-0,004349$ & 0,008114 \\
\hline Event 11 & $A R$ Sebelum & \multirow{2}{*}{41} & $-0,017338$ & 0,020125 & $-0,000349$ & 0,006902 \\
& $A R$ Setelah & & $-0,022056$ & 0,017118 & $-0,002001$ & 0,007496 \\
\hline Event 12 & $A R$ Sebelum & \multirow{2}{*}{45} & $-0,017353$ & 0,023343 & 0,000036 & 0,008085 \\
& $A R$ Setelah & & $-0,020844$ & 0,024390 & $-0,002246$ & 0,009293 \\
\hline & & & & & &
\end{tabular}

\section{Uji Normalitas}

Tabel 4 menunjukkan hasil pengujian normalitas data dengan one sample kolmogorov-smirnov. Didapati hasil bahwa dari 12 event yang diujikan terdapat 1 event yakni pada event 3 nilai signifikansi di bawah dari 0,05 sehingga dikatakan bahwa bahwa data tidak terdistribusi secara normal sehingga pada pengujian hipotesis pada event 3 (tanggal 22 Januari 2018) digunakan alternatif pengujian Non-parametrik yaitu Uji Wilcoxon.

Tabel 4

Ringkasan Hasil Uji Normalitas

\begin{tabular}{|c|c|c|c|c|}
\hline Event & Keterangan & $\mathbf{N}$ & $\begin{array}{l}\text { Asymp. Sig. (2- } \\
\text { tailed) }\end{array}$ & Kesimpulan \\
\hline Event 1 & $\begin{array}{l}\text { AR Sebelum } \\
A R \text { Setelah }\end{array}$ & 44 & $\begin{array}{l}0,200^{c, d} \\
0,096^{c, d}\end{array}$ & $\begin{array}{l}\text { Terdistribusi } \\
\text { Normal }\end{array}$ \\
\hline Event 2 & $\begin{array}{l}\text { AR Sebelum } \\
A R \text { Setelah }\end{array}$ & 45 & $\begin{array}{l}0,200^{c, d} \\
0,200^{c, d}\end{array}$ & $\begin{array}{l}\text { Terdistribusi } \\
\text { Normal }\end{array}$ \\
\hline Event 3 & $\begin{array}{l}A R \text { Sebelum } \\
A R \text { Setelah }\end{array}$ & 45 & $\begin{array}{l}0,001^{c} \\
0,013^{c}\end{array}$ & $\begin{array}{l}\text { Terdistribusi Tidak } \\
\text { Normal }\end{array}$ \\
\hline Event 4 & $\begin{array}{l}A R \text { Sebelum } \\
A R \text { Setelah }\end{array}$ & 45 & $\begin{array}{l}0,200^{c, d} \\
0,200^{c, d}\end{array}$ & $\begin{array}{l}\text { Terdistribusi } \\
\text { Normal }\end{array}$ \\
\hline Event 5 & $\begin{array}{l}\text { AR Sebelum } \\
A R \text { Setelah }\end{array}$ & 39 & $\begin{array}{l}0,075^{c, d} \\
0,200^{c, d}\end{array}$ & $\begin{array}{l}\text { Terdistribusi } \\
\text { Normal }\end{array}$ \\
\hline Event 6 & $\begin{array}{l}\text { AR Sebelum } \\
A R \text { Setelah }\end{array}$ & 45 & $\begin{array}{l}0,200^{c, d} \\
0,200^{c, d}\end{array}$ & $\begin{array}{l}\text { Terdistribusi } \\
\text { Normal }\end{array}$ \\
\hline Event 7 & $\begin{array}{l}A R \text { Sebelum } \\
A R \text { Setelah }\end{array}$ & 41 & $\begin{array}{l}0,200^{c, d} \\
0,133^{c}\end{array}$ & $\begin{array}{l}\text { Terdistribusi } \\
\text { Normal }\end{array}$ \\
\hline Event 8 & $\begin{array}{l}A R \text { Sebelum } \\
A R \text { Setelah }\end{array}$ & 37 & $\begin{array}{l}0,200^{c, d} \\
0,200^{c, d}\end{array}$ & $\begin{array}{l}\text { Terdistribusi } \\
\text { Normal }\end{array}$ \\
\hline Event 9 & $\begin{array}{l}A R \text { Sebelum } \\
A R \text { Setelah }\end{array}$ & 43 & $\begin{array}{l}0,200^{c, d} \\
0,132^{c, d}\end{array}$ & $\begin{array}{l}\text { Terdistribusi } \\
\text { Normal }\end{array}$ \\
\hline Event 10 & $\begin{array}{l}A R \text { Sebelum } \\
A R \text { Setelah }\end{array}$ & 44 & $\begin{array}{l}0,200^{c, d} \\
0,083^{c}\end{array}$ & $\begin{array}{l}\text { Terdistribusi } \\
\text { Normal }\end{array}$ \\
\hline Event 11 & $\begin{array}{l}A R \text { Sebelum } \\
A R \text { Setelah }\end{array}$ & 41 & $\begin{array}{l}0,200^{c, d} \\
0,200^{c, d}\end{array}$ & $\begin{array}{l}\text { Terdistribusi } \\
\text { Normal }\end{array}$ \\
\hline Event 12 & $\begin{array}{l}A R \text { Sebelum } \\
A R \text { Setelah }\end{array}$ & 45 & $\begin{array}{l}0,090^{c} \\
0,088^{c}\end{array}$ & $\begin{array}{l}\text { Terdistribusi } \\
\text { Normal }\end{array}$ \\
\hline
\end{tabular}

\section{Pengujian Hipotesis}

Hipotesis pada penelitian ini ialah menduga bahwa terdapat perbedaan abnormal return saham perusahaan pada indeks saham LQ45 sebelum dan setelah peristiwa perang dagang Amerika Serikat dan China. Penelitian ini menggunakan 12 event terkait peristiwa perang dagang tersebut. Pengujian hipotesis dilakukan dengan menggunakan tingkat signifikansi sebesar 5\% $(0,05)$.

Berdasarkan hasil uji normalitas data yang dilakukan,1 dari 12 event yang telah diujikan, terdapat 1 event yaitu pada event 3 hasil data tidak berdistribusi secara normal maka pada pengujian hipotesis, penelitian ini menggunakan pengujian non parametrik yaitu uji Wilcoxon. Sedangkan untuk event 1 , $2,4,5,6,7,8,9,10,11$, dan 12 yang memiliki hasil data berdistribusi secara normal, pengujian hipotesis menggunakan 
uji paired sample t-test dengan (taraf signifikansi 5\%). Berdasarkan hasil dari uji beda rata-rata abnormal return perusahaanperusahaan LQ45 pada masing-masing event yang di rangkum pada Tabel 5, keseluruhan event menunjukkan hasil signifikansi nilai Sig. (2 tailed) $>0,05$. Sehingga hipotesis penelitian yang diajukan pada penelitian ini yaitu terdapat perbedaan abnormal return signifikan sebelum dan setelah peristiwa terkait perang dagang Amerika Serikat dan China pada saham LQ45 tidak terbukti kebenarannya atau H1 ditolak. Hasil penelitian ini sejalan dengan hasil penelitian yang dilakukan oleh Satryo \& Wijayanto (2019), penelitian oleh Mannuela, Aditiya, \& Nicholas (2019) serta penelitian (Ridwan, 2018). Penelitian ini berbanding terbalik atau tidak sejalan dengan penelitian Putra \& Putri (2018) yang menggunakan estimasi waktu pengamatan 15 hari.

\begin{tabular}{|c|c|c|c|c|c|}
\hline \multicolumn{6}{|c|}{$\begin{array}{c}\text { Tabel 5 } \\
\text { Ringkasan Hasil Pengujian Hipotesis }\end{array}$} \\
\hline & \multirow[b]{2}{*}{ Pair } & \multicolumn{3}{|c|}{ Paired Sample Test } & \multirow{2}{*}{ Kesimpulan } \\
\hline & & $\mathrm{T}$ & $\mathrm{df}$ & Sig. (2-tailed) & \\
\hline Event 1 & Arit Sebelum dan setelah & 0,546 & 43 & 0,588 & H1 Ditolak \\
\hline Event 2 & Arit Sebelum dan setelah & 1,813 & 44 & 0,077 & H1 Ditolak \\
\hline Event 4 & Arit Sebelum dan setelah & $-1,577$ & 44 & 0,122 & H1 Ditolak \\
\hline Event 5 & Arit Sebelum dan setelah & $-1,186$ & 38 & 0,243 & H1 Ditolak \\
\hline Event 6 & Arit Sebelum dan setelah & $-0,666$ & 44 & 0,509 & H1 Ditolak \\
\hline Event 7 & Arit Sebelum dan setelah & $-1,559$ & 40 & 0,127 & H1 Ditolak \\
\hline Event 8 & Arit Sebelum dan setelah & 0,965 & 36 & 0,341 & H1 Ditolak \\
\hline Event 9 & Arit Sebelum dan setelah & 0,575 & 42 & 0,569 & H1 Ditolak \\
\hline Event 10 & Arit Sebelum dan setelah & $-0,914$ & 43 & 0,366 & H1 Ditolak \\
\hline Event 11 & Arit Sebelum dan setelah & 1,123 & 40 & 0,268 & H1 Ditolak \\
\hline Event 12 & Arit Sebelum dan setelah & 1,387 & 44 & 0,172 & H1 Ditolak \\
\hline
\end{tabular}

Tidak adanya perbedaan signifikan ratarata abnormal return sebelum dan setelah pada peristiwa perang dagang Amerika Serikat dan China karena update kebijakan atau pernyataan yang dikeluarkan oleh kedua belah pihak dinilai sebagai berita buruk bagi investor, sehingga investor lebih memilih menempatkan diri pada posisi wait and see (Satryo \& Wijayanto, 2019). Artinya investor menunggu arah lebih lanjut ke mana kebijakan tersebut, apakah ke depannya akan berdampak buruk bagi investor atau sebaliknya. Tidak adanya perbedaan signifikan pada persitiwa sebelum dan setelah perang dagang Amerika Serikat dan China mengindikasikan bahwa informasi yang terkandung dalam peristiwa tersebut tidak besar dan kuat, sehingga tidak mempengaruhi tingkat investasi dan keputusan investasi investor yang akan mempengaruhi abnormal return. Hal ini sejalan dengan penelitian event study yang dilakukan oleh Wijaya \& Gunawan (2019) meskipun dengan beda peristiwa. Faktor lain yang membuat pasar modal tidak bereaksi secara signifikan ialah salah satunya karena kondisi pertumbuhan ekonomi suatu negara tersebut yang dianggap stabil atau baik. Seperti yang dikatakan oleh Hartarto (2019) perang dagang Amerika tidak menjadi ancaman bagi Indonesia, bila melihat secara geopolitik nilai perdagangan impor dan ekspor Indonesia di negara Paman Sam yang berada pada urutan ke-17. Ini pun dibuktikan berdasarkan data Kementerian Koordinator bidang Perekonomian, Indonesia tercatat sebagai negara dengan pertumbuhan ekonomi terbesar kedua di antara negara G20 pada kuartal III-2019. Ekonomi Indonesia tumbuh 5,02\% pada kuartal III-2019 dikutip dari website Badan Pusat Statistik www.bps.go.id.

\section{KESIMPULAN DAN SARAN}

Penelitian ini bertujuan untuk mengetahui reaksi pasar modal Indonesia terhadap peristiwa perang dagang Amerika Serikat dan China. Kesimpulan yang diperoleh dari hasil penelitian ialah 1 dari 12 event berdasarkan hasil uji normalitas data, di mana pada event 3 hasil data tidak berdistribusi secara normal maka pada pengujian hipotesis menggunakan pengujian non parametrik yaitu uji Wilcoxon. Sedangkan untuk event $1,2,4,5,6,7,8,9$, 10, 11, dan 12 pengujian hipotesis menggunakan uji paired sample t test dengan 
(taraf signifikansi 5\%). Selain itu abnormal return saham LQ45 tidak bereaksi terhadap 12 event peristiwa perang dagang Amerika Serikat dan China sehingga dapat dikatakan bahwa 12 event terkait peristiwa perang dagang Amerika Serikat dan China tidak berpengaruh secara signifikan terhadap abnormal return saham LQ45.

Implikasi pada penelitian ini selain diharapkan menjadi referensi literatur bagi yang ingin melakukan penelitian serupa pada penelitian selanjutnya, tentunya bagi para investor dapat dijadikan sebagai dasar pengambilan keputusan khsusnya pada saat terjadi peristiwa politik luar negeri, sehingga investor dapat lebih cermat dalam mengambil keputusan dalam memilih menempatkan diri saat berinvestasi.

Beberapa saran penulis untuk penelitian selanjutnya diantaranya adalah agar menambahkan variabel trading volume activity. Selain itu penelitian selanjutnya dapat melakukan uji pengaruh sehingga dapat diketahui persentase pengaruh peristiwa. Penelitian lanjutan juga dapat mempertimbangkan untuk menggunakan variabel kontrol, seperti harga saham atau kurs mata uang dan waktu pengamatan yang lebih lama.

\section{DAFTAR PUSTAKA}

Brown, S. J., \& Warner, J. B. (1980). Measuring security price performance. Journal of financial economics, 8(3), 205258.

Dyckman, T., Philbrick, D., \& Stephan, J. (1984). A comparison of event study methodologies using daily stock returns:

A simulation approach. Journal of Accounting Research, 1-30.

Elad, F., \& Bongbee, N. (2016). Event study on the reaction of stock returns to acquisition news. Available at SSRN 2863243.

Hartono, P. (2015). Teori Portofolio dan Analisis Investasi. Edisi Kesepuluh. Yogyakarta: BPFE. YOGYAKARTA.

Hobbs, J., Schaupp, L. C., \& Gingrich, J. (2015). Terrorism, militarism, and stock returns. Journal of Financial Crime.
Hung, L.-C. (2013). U.S. Presidential Elections and the Taiwanese Stock Market. Issues \& Studies, 49(1), 71-79.

Li, X. M., \& Peng, L. (2017). US economic policy uncertainty and co-movements between Chinese and US stock markets. Economic Modelling, 61, 27-39.

Nugraha, C. A., \& Suroto, S. (2019). Abnormal Return and Trading Volume Activity Before and After Presidential Election 2019 (Study on LQ-45 stock on February-July 2019). Media Ekonomi dan Manajemen, 34(2).

Pham, H. N. A., Ramiah, V., Moosa, N., Huynh, T., \& Pham, N. (2018). The financial effects of Trumpism. Economic Modelling, 74, 264-274.

Ridwan, I. Z. (2018). Respon Investor Terhadap Pergantian Menteri Keuangan Republik Indonesia Periode 20 Mei 2013. Manajemen Bisnis, 5(1).

Saraswati, N. M. A. W., \& Mustanda, I. K. (2018). Reaksi Pasar Modal Indonesia Terhadap Peristiwa Pengumuman Hasil Penghitungan Suara Pemilihan Umum Dan Pelantikan Presiden Amerika Serikat. E-Jurnal Manajemen Universitas Udayana, 7(6).

Satryo, A. A., \& Wijayanto, A. (2019). Capital Market Reaction of Trade Wars (Event Study on the South Korean and Indonesia Stock Exchanges). Management Analysis Journal, 8(3), 253-264.

Shaikh, I. (2017). The 2016 US presidential election and the Stock, FX and VIX markets. The North American Journal of Economics and Finance, 42, 546-563.

Steinbock, D. (2018). US-China Trade War and Its Global Impacts. China Quarterly of International Strategic Studies, 4(04), 515-542.

Wijaya, K., \& Gunawan, H. (2019). Reaksi Pasar Modal Indonesia Terhadap Kesepakatan Investasi Antara Pemerintah Indonesia Dengan Pemerintah Arab Saudi. Journal of Applied Business Administration, 3(2), 306-316. 